\title{
Root extracts of Anacardium occidentale reduce hyperglycemia and oxidative stress in vitro
}

TM Archana, K Soumya, Jesna James and Sudheesh Sudhakaran*

\begin{abstract}
Background: Hyperglycemia is the hallmark of diabetes, and the associated oxidative stress is a major concern that invites an array of diabetic complications. The traditional practices of medicare are of great, current interest due to the high cost and side effects of conventional diabetic medications. The present in vitro study focuses on evaluating the potential of various A. occidentale root extracts for their antihyperglycemic and antioxidant potentials.

Materials and methods: The four different solvent extracts petroleum ether (PEAO), chloroform (CHAO), ethyl acetate (EAAO), and $80 \%$ methanol ( $80 \% \mathrm{MAO}$ ) of A. occidentale roots were evaluated for their total phenolic, flavonoid, and antioxidant capacity. Using MIN6 pancreatic $\beta$-cells, the cytotoxicity of the extracts was evaluated by MTT assay and the antidiabetic potential by quantifying the insulin levels by ELISA at a higher concentration of glucose. The effect of $80 \%$ MAO on INS gene expression was determined by qRT PCR analysis.

Results: Among the four different solvent extracts of A. occidentale roots, $80 \%$ MAO showed the highest concentration of phenolics (437.33 $\pm 0.03 \mu \mathrm{g}$ GAE/mg), CHAO to be a rich source of flavonoids (46.04 $\pm 0.1 \mu \mathrm{g} \mathrm{QE} / \mathrm{mg}$ ) and with the highest total antioxidant capacity $(1865.33 \pm 0.09 \mu \mathrm{g} \mathrm{AAE} / \mathrm{mg}$ ). Evaluation of the free radical scavenging and reducing properties of the extracts indicated $80 \% \mathrm{MAO}$ to exhibit the highest activity. The MTT assay revealed the least cytotoxicity of all four extracts. $80 \%$ MAO enhanced INS up-regulation as well as insulin secretion even under high glucose concentration ( $27 \mathrm{mM})$.

Conclusions: The present study demonstrated that the A. occidentale root extracts have effective antihyperglycemic and antioxidative properties, together with the potential of normalizing the insulin secretory system of $\beta$-cells. Above mentioned properties have to be studied further by identifying the active principles of $A$. occidentale root extracts and in vivo effects. The prospect of the present study is identifying drug leads for better management of diabetes from the A. occidentale root extracts.
\end{abstract}

Keywords: Anacardium occidentale, Pancreatic $\beta$-cells, INS gene, High glucose-induced oxidative stress, qRT PCR

\section{Introduction}

A coordinated interaction of the physiological processes Insulin secretion, glucose uptake by peripheral tissues, and hepatic glucose production is known to maintain glucose homeostasis in the body. Inadequacy in the maintenance of glucose homeostasis results in the chronic elevation of blood

* Correspondence: sudheeshs@kannuruniv.ac.in

School of Chemical Sciences, Kannur University, Payyanur campus, Edat P. O, Payyanur, Kerala 670327 Kannur, India

\section{Springer Open}

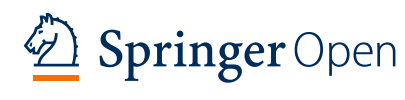

glucose levels [1]. Hyperglycemia, the forerunner and consistent marker of all types of diabetes and the concerning factor of diabetic complications has now become a challenge to the health systems. Hyperglycemia is often the result of insufficient secretion of insulin or its resistance which when prolonged results in microvascular and macrovascular complications [2]. The high glucose levels lead to altered metabolism, free radical generation, and induce apoptosis in $\beta$-cells and other cell types [3]. According to Robertson et al.'s perspectives, prolonged glucotoxicity is known to cause

The Author(s). 2021 Open Access This afticle is licensed under a Creative Commons Attribution 4.0 International License, which permits use, sharing, adaptation, distribution and reproduction in any medium or format, as long as you give appropriate credit to the original author(s) and the source, provide a link to the Creative Commons licence, and indicate if changes were made. The images or other third party material in this article are included in the article's Creative Commons licence, unless indicated otherwise in a credit line to the material. If material is not included in the article's Creative Commons licence and your intended use is not permitted by statutory regulation or exceeds the permitted use, you will need to obtain permission directly from the copyright holder. To view a copy of this licence, visit http://creativecommons.org/licenses/by/4.0/. 
decreased insulin gene expression. A major factor being the deficiency of PDX-1(Pancreas Duodenum Homeobox-1), an important transcription factor for the insulin promoter in glucotoxic $\beta$-cells. INS gene, almost exclusively expressed in $\beta$-cells of the pancreas is known to maintain the glucose homeostasis in the body and its defect results in impaired $\beta$ cell insulin secretory machinery ending up in diabetes mellitus [1].

The supraphysiological glucose level contributes to the generation of reactive oxygen species via autooxidation of glucose, via hexosamine metabolism, or oxidative phosphorylation during anaerobic glycolysis creating oxidative stress. A critical increase in the intraislet peroxide levels was observed during hyperglycemia, resulting in the deterioration of islet cells [4]. A weak manifestation of antioxidative enzymes in the pancreatic cells makes them more susceptible to oxidative stress. Thus, exogenous supplementation of antioxidants could protect the islet cells from the deteriorative effects of excess glucose levels [1]. Oxidative stress in the cells is well handled by antioxidants. The use of natural antioxidants from spices and herbs against oxidative stress has gained much attention over synthetic antioxidants due to the carcinogenic properties reported on synthetic antioxidants [5]. Studies have proven that many plant-derived compounds especially polyphenols like phenols and flavonoids are known to scavenge ROS and prevent lipid peroxidation [6].

Though many medications like sulfonylureas, biguanides, and incretins are used to curb diabetes, their bigbudget and side effects demanded the search for safer and cost-effective drugs [7]. Phytotherapy has been widely used to treat various ailments for thousands of years. Phytotherapy includes combination drugs comprising several different active compounds from plants. The traditional practice of curing disease though exhibited appreciated pharmacodynamics, the unrevealed scientific validation forms the concerning factor for promoting the use of traditional medicines [8].

Anacardium occidentale (cashew tree) is a member of the Anacardiaceae family. It is grown widely in tropical countries like Malaysia, India, Brazil, and Senegal. It is used as a folk remedy for treating diabetes mellitus by traditional practitioners of South Cameroon and other tropical countries [9]. The Anacardium plants are gaining much importance due to their nutritional and wide biological activities. Anacardium occidentale is considered to be versatile as every part of the tree produces resources and products. Its leaf, bark, root, and nutshell oil are used for medicinal purposes [10]. Literature supports the anti-hypoglycemic, anti-ulcerogenic, and acute toxicity effects of hydroethanolic leaf extracts of $A$. occidentale [11] and the analgesic and anti-inflammatory activity of cashew gum extract [12]. The bark of $A$. occidentale was known to be an antihyperglycemic agent as well as a detoxifier of snake-bites in Ayurveda [13]. Also, root infusion of $A$. occidentale was reported to be a notable purgative [14]. Literature also supports the crude methanolic extract of $A$. occidentale to be effective against postprandial hyperglycemia as it exhibited $\alpha$ amylase enzyme inhibition around $26.39 \%$ [15]. In vivo studies on the antihyperglycemic and antioxidative properties of $A$. occidentale leaves, stem bark has been reported, but not the effect of its root on diabetic parameters [16, 17]. Though the literature reports wide pharmacological activities of the plant, there are no such reports on the effect of roots of $A$. occidentale on the INS gene and insulin secretion. and hence, $A$. occidentale to be our plant of interest.

In this context, we have focused on providing a shred of scientific evidence for the use of this traditional medicine on diabetic parameters. The present study aims at investigating the antidiabetic potential of Anacardium occidentale root extracts to simultaneously attend the hyperglycemia and oxidative stress, normalizing the insulin secretory machinery of $\beta$-cells.

\section{Materials and methodology Chemicals}

The chemicals used for the study- Folin- Ciocalteu's reagent, sodium carbonate, aluminium chloride, potassium acetate, sodium phosphate, sulphuric acid, ammonium molybdate, potassium ferricyanide, trichloroacetic acid, ferric chloride, and solvents - petroleum ether, chloroform, ethyl acetate, and methanol were purchased from Merck, India Ltd., and the Biochemicals -Gallic acid, Quercetin, Ascorbic acid, DPPH (2, 2-diphenyl-1-picrylhydrazil) (Sigma Aldrich, Germany), DMEM (Dulbecco's Modified Eagle's Medium), and MTT (3, 4, 5-dimethylthiazol-2'-yl)-2, 5-diphenyltetrazolium bromide) from Sigma Aldrich, India.

\section{Plant Material and Extraction}

The roots of Anacardium occidentale were used as plant material. The samples were collected from local areas of the Kannur district, Kerala. The plant material was identified and authenticated by Dr. Sujanapal P., Senior Scientist, Department of Silviculture, Sustainable Forest Management Division, Kerala Forest Research Institute, Thrissur, Kerala, India, and the voucher specimen was deposited (Acc. No. 18017). The freshly collected plant material was chopped, shade dried, and ground to an optimal coarse powder. The powder was subjected to soxhlet extraction with solvents in their increasing polarity- petroleum ether, chloroform, ethyl acetate, and $80 \%$ methanol. The extracts were then evaporated to vacuum dryness and preserved in a desiccator for further use [18]. 


\section{Determination of Total Phenolic Content}

The total phenolics content in the four different solvent extracts of $A$. occidentale (PEAO, CHAO, EAAO, and $80 \%$ $\mathrm{MAO}$ ) was determined as per the procedure by Islam et al., A calibration curve was constructed using gallic acid as standard and the total phenolic content of the extract was determined spectrophotometrically (Shimadzu UV-1700 UV-Visible Spectrophotometer, Japan) with the Folin- Ciocalteu's reagent (FCR) and expressed as $\mu \mathrm{g}$ of Gallic Acid Equivalents/mg sample [19].

\section{Determination of Total Flavonoid Content}

Total flavonoids were estimated quantitatively by Aluminium Chloride Method [20]. Quercetin was used as the standard to make the calibration curve. Measurements were done in triplicates and the total flavonoid content of the extract was expressed as $\mu \mathrm{g}$ of Quercetin Equivalents/mg sample.

\section{Determination of Total Antioxidant}

The total antioxidant capacity of the four different solvent extracts of A. occidentale (PEAO, CHAO, EAAO, and $80 \%$ $\mathrm{MAO}$ ) was quantitatively determined spectroscopically (Shimadzu UV-1700 UV-Visible Spectrophotometer, Japan) through the formation of phosphomolybdenum complex. Total antioxidant capacity was calculated by the method described by Islam et al., [19]. From the ascorbic acid standard curve, the antioxidant capacity of samples of unknown composition was expressed as equivalents of ascorbic acid in $\mu \mathrm{g}$ per $\mathrm{mg}$ of the extract.

\section{Evaluation of Free radical scavenging activity (DPPH assay)}

The antioxidant activity of four different solvent extracts of A. occidentale (PEAO, CHAO, EAAO, and $80 \%$ $\mathrm{MAO}$ ) was evaluated using the 2, 2-diphenyl-1-picrylhydrazil (DPPH) radical scavenging method [21]. Ascorbic acid was used as standard. Every concentration was done in triplicate. The decrease in absorption of DPPH solution is calculated by the equation:

$$
\text { Inhibition }(\%)=\frac{A b s(\text { control })-A b s(\text { extract })}{A b s(\text { control }) \times 100}
$$

\section{Reducing Power Assay}

The reducing power of the samples was determined as described by Oyaizu M [22]. This method is based on the principle that an increase in the absorbance of the reaction mixtures indicates an increase in antioxidant activity. The absorbance of the samples was measured at $700 \mathrm{~nm}$ against a blank using UV-Visible
Spectrophotometer (Shimadzu UV-1700 UV-Visible Spectrophotometer, Japan) [23].

\section{Cell Culture Experiments}

MIN6 Cell lines were purchased from NCCS, Pune, India, and maintained in $25 \mathrm{~cm}^{2}$ tissue culture flasks with Dulbecco's Modified Eagle's Medium (DMEM) supplemented with L-glutamine, $10 \%$ FBS, Sodium bicarbonate, Penicillin $(100 \mathrm{U} / \mathrm{mL})$, Streptomycin $(100 \mu \mathrm{g} / \mathrm{mL})$ and Amphotericin B $(2.5 \mu \mathrm{g} / \mathrm{mL})$. The culture flasks were incubated at $37^{\circ} \mathrm{C}$ in a humidified $5 \% \mathrm{CO}_{2}$ incubator (NBS Eppendorf, Germany). The cells were subcultured by trypsinization and maintained in DMEM. The experiments were performed twice in triplicates.

\section{In vitro Cytotoxicity Assay}

The cytotoxicity of the four different solvent extracts of A. occidentale (PEAO, CHAO, EAAO, and $80 \% \mathrm{MAO}$ ) was evaluated by MTT Assay (3, 4, 5-dimethylthiazol-2'yl)-2, 5-diphenyltetrazolium bromide) in MIN6 pancreatic cells [24]. All absorbance values were corrected against blank wells which contained growth media alone. For each test concentration, the mean absorbance of the triplicated wells was calculated. Mean absorbance of the cells grown in the absence of test compound was taken as $100 \%$ cell survival.

Percentage cell viability was calculated by using the following formula,

$$
\% \text { Cell viability }=\frac{\text { Absorbance of sample } x 100}{\text { Absorbance of control }}
$$

\section{$\beta$-Cell assay}

MIN6 cell lines maintained in DMEM were trypsinized from the plate, splitted, and replated to maxisorb 6 well plates. The confluent cells were incubated with Krebs Ringers Buffer for $1 \mathrm{~h}$ and then washed cells twice with KRB. An aliquot of second wash (with KRB) is saved for baseline insulin measurement. The cells were then incubated for $1 \mathrm{~h}$ with KRB

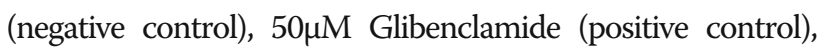
$0.1 \%$ DMSO (vehicle control), the non-cytotoxic range of concentration of the four extracts as per the MTT assay in the presence $(27 \mathrm{mM})$, and absence of glucose. The insulin levels of the treated solutions were quantified by Indirect ELISA [25].

\section{RNA Isolation and Real-Time PCR Analysis}

The cells were lysed and the total cellular RNA was isolated using Qiazol reagent (Qiagen, Germany). The RNA was then treated with chloroform, centrifuged (13,000 rpm for $15 \mathrm{mi}-$ nutes at $4{ }^{\circ} \mathrm{C}$ ), and finally precipitated with isopropyl alcohol. The quantitative yield of RNA was determined by 
Qubit ${ }^{\circ}$ 4.0 Fluorometer. The primer used for INS was F- 5' GCCCTTAGTGACCAGCTATAATC3'and R-5' GGACCA CAAAGATGCTCTTTG 3' and F-5'CATCCGTAAAGACC TCTATGCC3' and R-5' GACTCATCGTACTCCTGCTT G3' for $\beta$-actin. cDNA synthesis was done using Thermo Scientific RevertAid First Strand cDNA Synthesis Kit followed by real-time PCR measurements of INS and $\beta$-actin with CFX Connect Real-Time PCR Detection System (Biorad, Japan) with reaction volume $-6 \mu \mathrm{L}$, containing $2 \mathrm{X}$ Real-Time PCR smart mix- $3 \mu \mathrm{L}$, Forward primer + Reverse primer$0.5 \mu \mathrm{L}$, Template cDNA $-1 \mu \mathrm{L}$ and nuclease-free water $1.5 \mu \mathrm{L}$. The cycling conditions were Polymerase activation: $95{ }^{\circ} \mathrm{C}$ for $10 \mathrm{~min}$, Denaturation: $95^{\circ} \mathrm{C}$ for $15 \mathrm{~s}$, and Annealing/extension: $60{ }^{\circ} \mathrm{C}$ for $1 \mathrm{~min}$ and the reaction was repeated to 40 cycles [26].

\section{Statistical Analysis}

Statistical analyses were performed using GraphPad Instat (version 3.05) software. All the results are expressed in mean \pm SD for triplicate determinations and the data were analyzed by one-way analysis of variance (ANOVA) followed by Dunnett's post-test. The concentration needed for $50 \%$ inhibition $\left(\mathrm{IC}_{50}\right.$ ) was estimated graphically by linear regression analysis.

\section{Results and discussion}

\section{Extraction Yield of four different solvent extracts of}

\section{Anacardium occidentale roots}

No single solvent is reliable for the extraction of the whole phytoconstituents from a plant. Sequential extraction with solvents of increasing polarity (nonpolar to polar) was selected for the study. This ensures the extraction and separation of a wide range of phytoconstituents from plant materials. Solvent polarity significantly reflects the extract yield and pharmacological properties of the plant material [18]. The extract yield from different fractions was calculated by using the equation:

$$
\text { Percentage extract yield }(w / w)=\frac{\text { Dry extract weight } \times 100}{\text { Dry starting material weight }}
$$

The percentage extract yield from all eight samples is given in Table 1.

\section{Amount of total phenolic and flavonoid content in the four different solvent extracts of $A$. occidentale}

The total phenolic content and total flavonoid content of the four different solvent extracts of $A$. occidentale roots (PEAO, CHAO, EAAO, and $80 \%$ MAO) determined by Folin- Ciocalteu's reagent and Aluminium chloride method revealed that the extracts contained more phenolics than flavonoids. Among the four extracts, $80 \%$ MAO $(437.33 \pm 0.03 \mu \mathrm{g}$ of $\mathrm{GAE} / \mathrm{mg}$ extract $)$ contained the highest amount of phenolics and $\mathrm{CHAO}$ to be a rich source of flavonoids $(46.04 \pm 0.1 \mu \mathrm{g}$ of $\mathrm{QE} /$ mg extract) (Table 2).

Total antioxidant capacity of four different solvent extracts of $A$. occidentale

The antioxidants present in the extract reduce Mo (VI) to a green phosphate Mo (V) complex. All extracts showed notable antioxidant capacity. The $\mathrm{CHAO}$ extract showed the highest antioxidant capacity with $1865.33 \pm$ $0.09 \mu \mathrm{g}$ of ascorbic acid per mg of the extract, followed by PEAO, EAAO, and finally $80 \%$ MAO (Table 2).

\section{DPPH scavenging activity of four different solvent extracts of $A$. occidentale}

The ability of the plant extracts as antioxidants were reckoned concerning their ability to scavenge the DPPH; the higher the percentage inhibition, the higher the antioxidant property corresponding to the increasing concentration of extracts. Among the four extracts, $80 \% \mathrm{MAO}$ showed the strongest scavenging activity with an $\mathrm{IC}_{50}$ value of $0.026 \pm 0.5 \mathrm{mg} / \mathrm{mL}$, pursued by EAAO with an $\mathrm{IC}_{50}$ value of $0.031 \pm 0.12 \mathrm{mg} / \mathrm{mL}$ and that was comparable with the standard ascorbic acid $\left(\mathrm{IC}_{50}=0.011 \pm\right.$ $0.3 \mathrm{mg} / \mathrm{mL}$ ). PEAO showed the lowest antioxidant property with $\mathrm{IC}_{50}$ value $6.12 \pm 1.1 \mathrm{mg} / \mathrm{mL}$. CHAO also exhibited a significant $\mathrm{DPPH}$ scavenging activity $\left(\mathrm{IC}_{50}=3.71 \pm\right.$ $0.63 \mathrm{mg} / \mathrm{mL}$ ) compared to standard ascorbic acid (Fig. 1).

\section{Reducing power activity of four different solvent extracts} of $A$. occidentale

Figure 2 represents the reducing power of the four different solvent extracts of $A$. occidentale roots (PEAO, CHAO, EAAO, and $80 \%$ MAO). The increasing absorbance indicates an increase in the reducing power of the extracts. $80 \%$ MAO exhibited an excellent reducing power with an $\mathrm{IC}_{50}$ value of $9.59 \pm$ $0.71 \mathrm{mg} / \mathrm{mL}$ that was comparable with the standard ascorbic acid $\left(\mathrm{IC}_{50}=9.22 \pm 1.87 \mathrm{mg} / \mathrm{mL}\right)$ and followed by $\mathrm{EAAO}>\mathrm{CHAO}>\mathrm{PEAO}$ in their decreasing order of activity.

Cytotoxic effect of four different solvent extracts of $A$. occidentale root extracts against MIN6 cells

The four different solvent extracts of $A$. occidentale roots (PEAO, CHAO, EAAO, and $80 \% \mathrm{MAO}$ ) were screened for their cytotoxic effect by MTT assay in MIN6 cells. The extracts were tested at doses ranging from $100,50,25,12.5,6.25,3.12$, and $1.56 \mu \mathrm{g} / \mathrm{mL}$, and the percentage viability of cells corresponding to each concentration was calculated (Table 3.). A control well with untreated cells was maintained taking $100 \%$ cell viability. 
Table 1 The percentage yield of extracts of Anacardium occidentale roots

\begin{tabular}{llll}
\hline Species & Part used & Extract yield (\% w/w) & \\
\hline A.occidentale & Roots & Petroleum ether & 0.1 \\
& & Chloroform & 0.2 \\
& & Ethyl acetate & 0.4 \\
& 80\% Methanol & 7.5 \\
\hline
\end{tabular}

\section{Effect of four different solvent extracts of $A$. occidentale root extracts on Insulin secretion in MIN6 cells}

The hypoglycemic activity of PEAO, CHAO, EAAO and $80 \%$ MAO were tested by their potential in stimulating insulin secretion from cells in the presence and absence of glucose; glucose being a key regulator for the secretion of insulin from $\beta$ - cells. The cells treated with extracts at $12.5 \mu \mathrm{g} / \mathrm{mL}$ concentration (Non-toxic concentration as per MTT Assay) and checked for insulin secretion by indirect ELISA revealed that $80 \% \mathrm{MAO}$ to be a potent insulin secretagogue. Though the insulin levels were less in $80 \%$ MAO treated cells compared to the control in the absence of glucose, the insulin levels were raised to an appreciated level in the same group in the presence of a high glucose concentration $(27 \mathrm{mM})$. The standard drug glibenclamide exhibited a similar effect compared to the $80 \%$ MAO fraction. Though $80 \%$ MAO fraction and glibenclamide showed similar effects, comparatively higher insulin levels were observed in $80 \%$ MAO fraction treated cells. The other fractions: PEAO, CHAO, and EAAO promoted insulin secretion to a better level than the control group in the absence and presence of glucose. But, in presence of high glucose concentration, the extracts showed a comparatively lesser amount of insulin correlated to the same treatment groups in the absence of glucose. Similarly, a decrease in insulin level was observed in the control group in presence of glucose than in its absence. This observation suggests hyperglycemia impairs the insulin secretory machinery of $\beta$-cells and that the extracts PEAO, CHAO, and EAAO could be ruled out as antidiabetic agents. (Fig. 3).

\section{Effect of $80 \%$ methanolic fraction of $A$. occidentale roots on INS gene expression}

The effect of $80 \%$ methanolic fraction of $A$. occidentale roots in stimulating glucose-dependent insulin secretion was quantitatively analyzed by Real-time PCR. The expression of the INS gene in effect to the standard drug Glibenclamide and $80 \%$ MAO revealed that the $80 \%$ methanolic fraction of $A$. occidentale roots up-regulated the gene to a greater extent than the control and Glibenclamide. The test group treated with glucose alone $(27 \mathrm{mM})$ exhibited down-regulation of the INS gene. (Fig. 4).

\section{Discussion}

Glucose is the key regulator of insulin synthesis and secretion. However, exposure of $\beta$-cells to supraphysiological glucose concentration results in incessant stimulation of the cells leading to insulin store exhaustion and reduced insulin secretion, impaired insulin gene expression, generation of oxidative stress, and apoptosis of the cells [27]. Thus, managing hyperglycemia has become an inevitable factor for the prevention of diabetes and its associated complications. Also, recovering the deteriorated $\beta$-cells and normalizing its function, and maintaining the gene expression even in the hyperglycemic environment offers a therapeutic means of preventing the onset of diabetes; where our study becomes substantial. In the present study, we have investigated the effect of petroleum ether, chloroform, ethyl acetate, and $80 \%$ methanol extracts of $A$. occidentale roots to promote insulin secretion while protecting the $\beta$ - cells and INS gene expression from hyperglycemia and associated oxidative stress. In this study, the MIN6 pancreatic $\beta$-cells when incubated in the absence and presence of a high concentration of glucose $(27 \mathrm{mM})$ and the four extracts of $A$. occidentale roots (PEAO, CHAO, EAAO, and $80 \%$ $\mathrm{MAO}), 80 \% \mathrm{MAO}$ at concentration $12.5 \mu \mathrm{g} / \mathrm{mL}$ was found to be a potent insulin secretagogue. In addition, $80 \%$ MAO exhibited a significant level of insulin in presence of $27 \mathrm{mM}$ of glucose and was higher than that in Glibenclamide treated group. Thus, our data demonstrate that $80 \%$ MAO could promote insulin secretion even under hyperglycemic conditions. The present study can be correlated to the in vitro study by Keller et al., in MIN6 pancreatic $\beta$-cells. The study reported that the saponins momordicine II and kuguaglycoside G from the traditional plant Momordica charantia at concentrations 10 and $25 \mu \mathrm{g} / \mathrm{mL}$ respectively stimulated insulin secretion under high concentrations of glucose $(27 \mathrm{mM})$ [25].

The Insulin gene (INS) almost exclusive to pancreatic cells encodes for the pancreatic hormone insulin that is secreted uniquely by the $\beta$-cells [28]. Insulin maintains glucose metabolism and blood glucose homeostasis by binding to specific insulin receptors expressed by the hepatic, muscle, and adipose cells through a cascade of biochemical reactions. A lack of production or abnormalities in the secretion or improper response of cells to insulin can lead to the pathogenesis of all types of diabetes and mainly type I Diabetes mellitus and type II Diabetes mellitus [29]. In vivo study by Harmon et al., in type 2 diabetes models reported that persistent exposure of $\beta$-cells to high glucose levels would distress insulin 
Table 2 Amount of total phenolic and flavonoid contents and total antioxidant capacity of Petroleum ether, Chloroform, Ethyl acetate, and $80 \%$ Methanolic Extracts of A. occidentale roots

\begin{tabular}{lccc}
\hline A. occidentale Extracts & TPC $(\boldsymbol{\mu g}$ of GAE$/ \mathbf{m g})$ & TFC $(\boldsymbol{\mu g}$ of QE/mg) & TAC $(\boldsymbol{\mu g}$ of AAE/mg) \\
\hline PEAO & $390.67 \pm 0.08$ & $13.96 \pm 0.07$ & $1315.33 \pm 0.2$ \\
CHAO & $404 \pm 0.11$ & $46.04 \pm 0.10$ & $1865.33 \pm 0.09$ \\
EAAO & $407.33 \pm 0.16$ & $32.83 \pm 0.12$ & $552 \pm 0.23$ \\
$80 \%$ MAO & $437.33 \pm 0.03$ & $21.51 \pm 0.09$ & $552 \pm 0.12$ \\
\hline
\end{tabular}

TPC Total phenolic content, TFC Total flavonoid content, TAC Total antioxidant capacity, GAE Gallic acid equivalents, QE Quercetin equivalents, AAE Ascorbic acid equivalents; PEAO Petroleum ether extract of $A$. occidentale, $C H A O$ Chloroform extract of $A$. occidentale, EAAO Ethyl acetate extract of $A$. occidentale, $80 \%$ MAO $80 \%$ Methanol extract of $A$. occidentale

*Results are expressed as mean \pm SD $(n=3)$

gene expression and thereby insulin secretion and therefore preventing hyperglycemia could preserve insulin and PDX-1 gene expression [30]. From the Real-Time PCR analysis, a double fold up-regulation in the INS gene was observed in the cells treated with $80 \%$ MAO compared to Glibenclamide. This reinforces the finding that $80 \%$ MAO could stimulate insulin secretion both at its transcriptional and translational level while managing hyperglycemia. The downregulation of the gene in the test group treated with glucose alone $(27 \mathrm{mM})$, further confirms the finding of Harmon et al.

Earlier studies report that high glucose levels could induce $\beta$-cell apoptosis mainly because of oxidative stress [31] and thereby declined insulin content in the cell [32]. A weak expression of antioxidant enzymes is exhibited by the pancreatic islets, which makes them more susceptible to oxidative stress $[1,4]$. The continuous exposure of cells to oxidative stress results in the

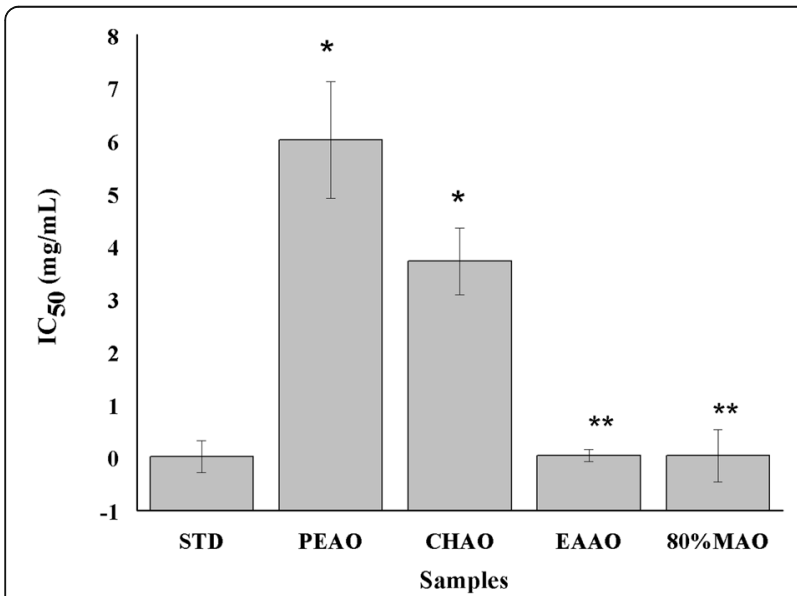

Fig. 1 DPPH scavenging activity of Petroleum ether, Chloroform, Ethyl acetate, and $80 \%$ Methanol Extracts of $\boldsymbol{A}$. occidentale. ${ }^{*}$ PEAO: Petroleum ether extract of A. occidentale, CHAO: Chloroform extract of A. occidentale, EAAO: Ethyl acetate extract of A. occidentale, $80 \%$ MAO: $80 \%$ Methanol extract of A. occidentale. ${ }^{*}$ Results are expressed as mean $\pm \mathrm{SD}(n=3) .{ }^{\prime * \prime}$ indicates values significantly differ from the standard at $P^{<} 0.001 .{ }^{* * * \prime}$ indicates values significantly differ from the standard at $P^{<} 0.05$. generation of ROS in mitochondria and also in the formation of intracellular glycation end products that glycate the antioxidants making the $\beta$-cells further deprived of antioxidative enzymes [10]. Also, it is the single hyperglycemia that causes the overproduction of superoxides by the mitochondrial electron transport chain and ends up in diabetes-specific microvascular disease, a prime cause for retinopathy, nephropathy, neuropathy, and myocardial infarction [10]. $80 \%$ MAO protects the $\beta$-cells from hyperglycemia-induced oxidative stress which in turn helped normalize the insulin secretory machinery of the cells. This observation is strengthened by the significant free radical scavenging $\left(\mathrm{IC}_{50}=0.026 \pm\right.$ $0.5 \mathrm{mg} / \mathrm{mL})$ and the reducing power $\left(\mathrm{IC}_{50}=9.59 \pm\right.$ $0.71 \mathrm{mg} / \mathrm{mL}$ ) of the extract. Besides, $80 \%$ MAO exhibited an appreciated amount of phenolic and flavonoid content as well as total antioxidant capacity compared to PEAO, CHAO, and EAAO, which further strengthens its

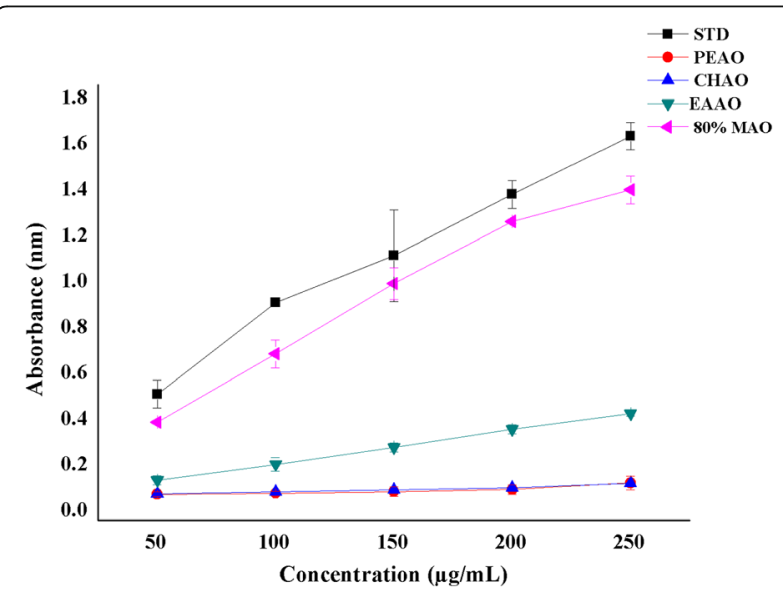

Fig. 2 Reducing power activity of Petroleum ether, Chloroform, Ethyl acetate, and $80 \%$ Methanol Extracts of $\boldsymbol{A}$. occidentale. ${ }^{*}$ PEAO: Petroleum ether extract of A. occidentale, CHAO: Chloroform extract of A. occidentale, EAAO: Ethyl acetate extract of A. occidentale, $80 \%$ MAO: $80 \%$ Methanol extract of A. occidentale. ${ }^{*}$ Results are expressed as mean $\pm \mathrm{SD}(n=3)$. 
Table 3 Percentage Cell Viability of Petroleum ether, Chloroform, Ethyl acetate, and 80 \% Methanolic Extracts of A. occidentale roots against MIN6 cells

\begin{tabular}{lllll}
\hline $\begin{array}{l}\text { Concentration } \\
(\boldsymbol{\mu g} / \mathrm{mL})\end{array}$ & \multicolumn{2}{l}{ Cell Viability $(\%)$} & & \\
\cline { 2 - 4 } & PEAO & CHAO & $80 \%$ & EAAO \\
\hline 100 & $83.94 \pm 0.006^{*}$ & $82.89 \pm 0.004^{*}$ & $88.24 \pm 0.001^{*}$ & $81.90 \pm 0.006^{*}$ \\
50 & $86.92 \pm 0.004^{*}$ & $87.44 \pm 0.005^{*}$ & $92.49 \pm 0.007^{*}$ & $83.00 \pm 0.001^{*}$ \\
25 & $90.86 \pm 0.005^{*}$ & $90.41 \pm 0.002^{*}$ & $96.06 \pm 0.008^{*}$ & $87.83 \pm 0.004^{*}$ \\
12.5 & $95.45 \pm 0.005^{*}$ & $92.35 \pm 0.006^{*}$ & $99.29 \pm 0.004^{*}$ & $90.05 \pm 0.008^{*}$ \\
6.25 & $98.31 \pm 0.005^{*}$ & $95.83 \pm 0.008^{*}$ & 100 & $92.23 \pm 0.003^{*}$ \\
3.12 & $99.49 \pm 0.003^{*}$ & $97.68 \pm 0.003^{*}$ & 100 & $97.24 \pm 0.004^{*}$ \\
1.56 & 100 & $99.29 \pm 0.002^{*}$ & 100 & $99.15 \pm 0.003^{*}$
\end{tabular}

PEAO Petroleum ether extract of $A$. occidentale, CHAO Chloroform extract of $A$. occidentale, EAAO Ethyl acetate extract of $A$. occidentale, $80 \%$ MAO $80 \% \mathrm{Methanol}$ extract of $A$. occidentale

* Results are expressed as mean $\pm \mathrm{SD}(n=3) . P^{<} 0.05$ vs. control

antioxidant efficacy. The phenolic and flavonoid compounds are known for their antioxidant property; they are used as anti-oxidative agents. The hydroxyl group in phenolics acts as a free radical scavenger and thus, a positive relationship between total phenolics and the antioxidant property is observed in plant species [33]. Kaemferol, a flavonol at $10 \mu \mathrm{M}$ concentration protected pancreatic $\beta$-cells from apoptosis and promoted better cell viability and function under chronic hyperglycemic function [34]. The antioxidant property of A.occidentale is attributed to its polyphenol content. The ultrasonic extraction of cashew leaves yielded antioxidative phenolics. An increase in the total phenolic content (579.55 mg GAE/g) of the extract increased its reducing power $(10.28 \pm 0.21 \mathrm{mmol} \mathrm{TE} / \mathrm{g})$ and free radical scavenging $(12.14 \pm 0.01 \mathrm{mmol} \mathrm{TE} / \mathrm{g})$ properties and thus, the extract exhibited a protective effect towards DNA damage by peroxyl radical [35]. This result is consistent with our findings on the phenolic content and antioxidant properties of $80 \% \mathrm{MAO}$.

\section{Conclusions}

The antidiabetic efficacy of the four sequentially solvent-extracted fractions Petroleum ether (PEAO), Chloroform (CHAO), Ethyl acetate (EAAO), and $80 \%$ Methanol ( $80 \%$ MAO) of Anacardium occidentale roots evaluated at concentration $12.5 \mu \mathrm{g} / \mathrm{mL}$ in MIN6 pancreatic $\beta$ - cell lines revealed $80 \%$ MAO to exhibit potent antidiabetic activity by promoting insulin secretion both at its transcriptional and translation

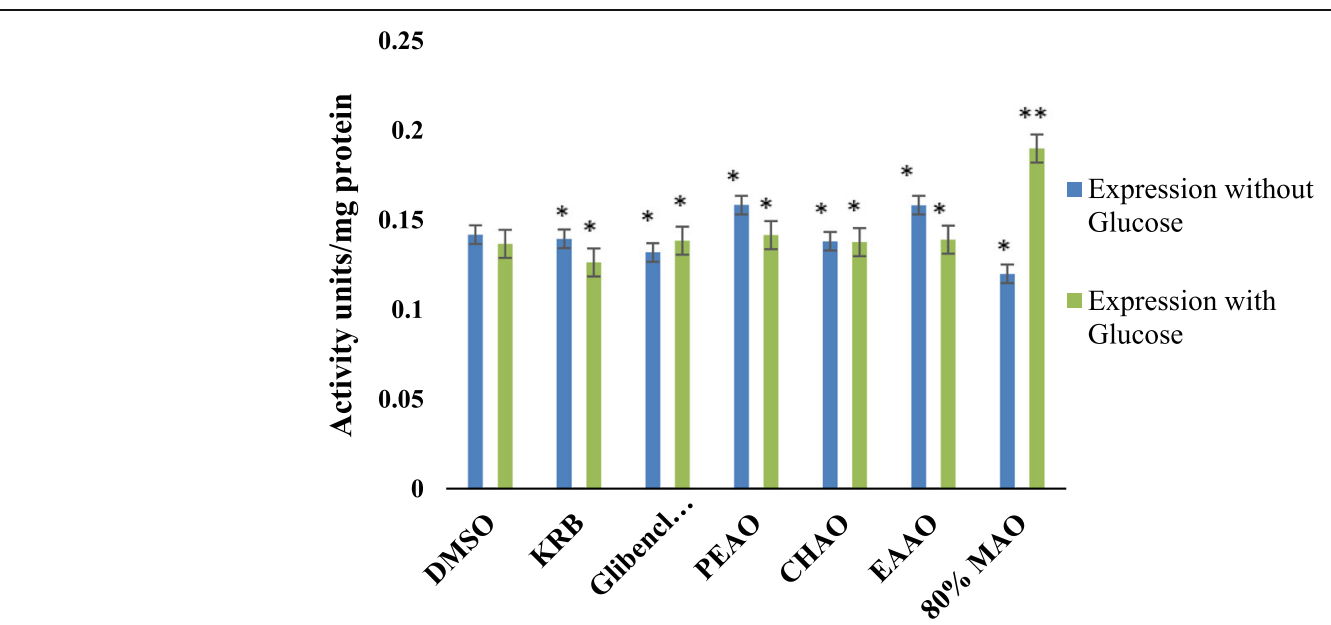

Fig. 3 Effect of four different solvent extracts of $\boldsymbol{A}$. occidentale roots on Insulin secretion in MIN6 cells in the presence (27mM) and absence of Glucose. * DMSO: Dimethyl sulfoxide, KRB: Krebs Ringers Buffer, PEAO: Petroleum ether extract of A. occidentale, CHAO: Chloroform extract of A. occidentale, EAAO: Ethyl acetate extract of A. occidentale, $80 \%$ MAO: $80 \%$ Methanol extract of A. occidentale.*' indicates values significantly differ from Control at $P^{<} 0.05 .{ }^{{ }^{*} *{ }^{\prime \prime}}$ indicates values significantly differ from the standard at $P^{<} 0.01$. 


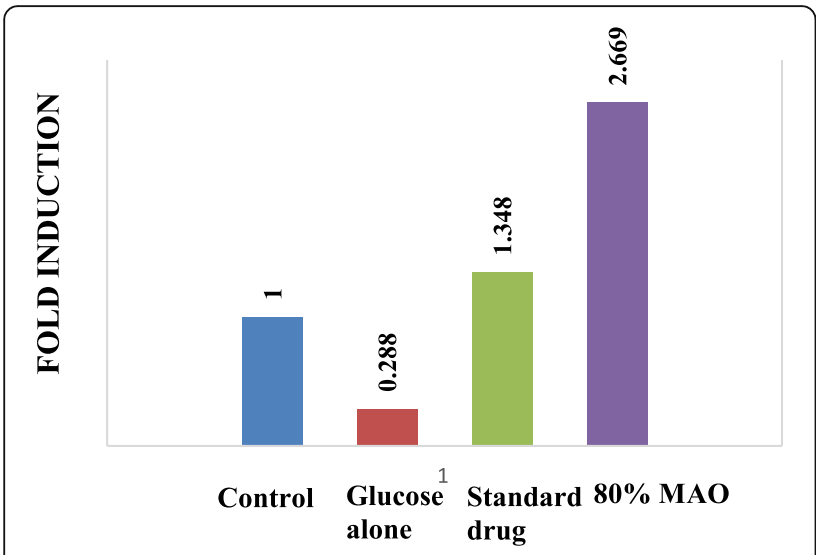

Fig. 4 Graphical Representation of Real-Time PCR Analysis of INS gene expression

level. The potent antioxidant activity, as well as the ability of the fraction to promote insulin synthesis and secretion even at a higher level of glucose (27 $\mathrm{mM}$ ), indicates the capacity of the extract to protect the $\beta$-cells from oxidative stress. The $80 \%$ methanolic extract of $A$. occidentale roots thus, offers a promising lead drug candidate in developing an antidiabetic drug that even could attend to complications associated with diabetes. Above mentioned properties have to be studied further by identifying the active principles of A. occidentale root extracts and in vivo effects. The prospect of the present study is identifying drug leads for better management of diabetes from the A. occidentale root extracts.

\section{Abbreviations}

PEAO: Petroleum ether fraction of Anacardium occidentale roots; CHAO: Chloroform fraction of Anacardium occidentale roots; EAAO: Ethyl acetate fraction of Anacardium occidentale roots; $80 \%$ MAO: $80 \%$ methanol fraction of Anacardium occidentale roots; INS: Insulin gene

\section{Acknowledgements}

We acknowledge Kannur University for the support.

\section{Authors' contributions}

Archana T. M. executed the experimental part, analyzed the data, and drafted the manuscript. Dr. Sudheesh S. guided the study by designing and coordinating the work. Soumya K. and Jesna James helped in drafting the manuscript. All authors read and approved the final manuscript.

\section{Funding}

The author (Archana T.M. and Dr. Sudheesh S., Mentor) hereby thankfully acknowledge Kerala State Council for Science, Technology, and Environment (KSCSTE-WSD) (Reference Number- No. 57/WSD-BLP/2018) for the financial support.

\section{Availability of data and materials}

All data generated or analyzed during the present study are available from the corresponding author on reasonable request.

\section{Declarations}

All the authors have read and approved the manuscript and agree with its submission to the journal. This manuscript has not been published elsewhere and is not under consideration by any other journal.

\section{Ethics approval and consent to participate}

NA.

\section{Consent for publication}

NA.

\section{Competing interests}

The authors declare that they have no competing interests.

Received: 7 January 2021 Accepted: 10 June 2021

Published online: 24 June 2021

\section{References}

1. Robertson PR, Harmon J, Tran OP, Tanaka Y, Takahashi H. Glucose toxicity in $\beta$-cell: Type 2 Diabetes, good radicals gone bad, and the glutathione connection. Diabetes. 2003;52:581-7. doi:https://doi.org/10.2337/diabetes. 52.3.581.

2. Brownlee M. Biology of diabetic complications. 2001;414(12):813-20.

3. Fridlyand $L E$, Philipson $L H$. Does the glucose-dependent insulin secretion mechanism itself cause oxidative stress in pancreatic beta-cells? Diabetes. 2004;53(8):1942-8. doi:https://doi.org/10.2337/diabetes.53.8.1942.

4. Kawahito S, Kitahata H, Oshita S. Problems associated with glucose toxicity: role of hyperglycemia-induced oxidative stress. World J Gastroenterol. 2009; 15(33):4137-42. doi:https://doi.org/10.3748/wjg.15.4137.

5. Vijayakumar A, Kalaichelvan PT. Antioxidant And Antimicrobial Activity Using Different Extracts Of Anacardium Occidentale L. IJABPT. ISSN 0976-4. 2011; (3):436-43.

6. Jahan N, Parvin MS, Das N, Islam MS, Islam ME. Studies on the antioxidant activity of ethanol extract and its fractions from Pterygota alata leaves. $J$ Acute Med. 2014;4(3):103-8. Available from: https://doi.org/10.1016/j.jacme.2 014.05.001.

7. Sulaimon LA, Anise EO, Obuotor EM, Samuel TA, Moshood Al, Olajide M, Fatoke T. In vitro antidiabetic potentials, antioxidant activities and phytochemical profile of african black pepper (Piper guineense). Clinical Phytoscience. 2020;6(1):1-3.

8. Taylor JL, Rabe T, McGaw LJ, Jäger AK, Van Staden J. Towards the scientific validation of traditional medicinal plants. Plant Growth Regul. 2001;34(1):23-37.

9. Jaiswal YS, Tatke PA, Gabhe SY, Vaidya AB. Antidiabetic activity of extracts of Anacardium occidentale Linn. leaves on $\mathrm{n}$-streptozotocin-diabetic rats. J Tradit Chinese Med Sci. 2016. https://doi.org/10.1016/j.jtcme.2016.11.007.

10. Iyare Gl, Omorodion NT, Erameh TO, et al. The effects of Anacardium occidentale leave extract on histology of selected organs of Wistar rats. MOJ Biol Med. 2017;2(2):216-21. DOl:https://doi.org/10.15406/mojbm.2017.02. 00046.

11. Andr N, Bacchi EM. Antiulcerogenic effect and acute toxicity of a hydroethanolic extract from the cashew (Anacardium occidentale L.) leaves. J Ethnopharmacol. 2007. https://doi.org/10.1016/j.jep.2007.03.003.

12. Priscilla D, Ferreira I, Kelle L, Ferreira A, Vale V, Ferreira M, Adriana G, Gontijo $B$, Pereira-junior MA Chemical characterization and pharmacological assessment of polysaccharide free, standardized cashew gum extract (Anacardium occidentale L.). J. Ethnopharmacol. 2018; https://doi.org/10.101 6/j.jep.2017.11.021.

13. Bown D. (1995). Encyclopedia of Herbs and their Uses. Dorling Kindersley, London. ISBN 0-7513-020-31.

14. PDR for Herbal Medicines. (2007). PDR (Physicians' Desk Reference) Staff Fourth Edition. Thomson. 1563636786.

15. Sunday O, Oyedemi BO, Oyedemi II, ljeh PE, Ohanyerem RM, Coopoosamy, Olayinka A, Aiyegoro. Alpha-amylase inhibition and antioxidative capacity of some antidiabetic plants used by the traditional healers in Southeastern Nigeria. The Scientific World Journal. 2017. https://doi.org/10.1155/2017/3 592491.

16. Ukwenya VO, Ashaolu JO, Adeyemi AO, Akinola OA, Caxton-Martins EA. Antihyperglycemic activities of methanolic leaf extract of Anacardium occidentale (Linn.) on the pancreas of streptozotocin-induced diabetic rats. 2012;6:169-74. 
17. Singh R. Antihyperglycemic effect of ethanolic extract and fractions of Anacardium occidentale L. stem bark in streptozotocin-induced diabetic rats. J Basic Clin Pharm. 2009;1 (1):16-9. PMID: 25206248.16.

18. Nawaz Haq S, Muhammad R, Najiha A, Hina, Najeeb U. Effect of solvent polarity on extraction yield and antioxidant properties of phytochemicals from bean (Phaseolus vulgaris) seeds. Brazilian Journal of Pharmaceutical Sciences. 2020; 56. https://doi.org/10.1590/s2175-97902019000417129.

19. Islam E, Islam R, Rahman AA, Alam AHMK, Khondkar P. Estimation of total phenol and in vitro antioxidant activity of Albizia procera leaves. BMC Research Notes.2013; http://www.biomedcentral.com/1756-0500/6/121.

20. Sushant Aryal MK, Baniya K, Danekhu P, Kunwar. Roshani Gurung and Niranjan Koirala. Total Phenolic Content, Flavonoid Content and Antioxidant Potential of Wild Vegetables from Western Nepal. Plants. 2019. doi:https:// doi.org/10.3390/plants8040096.

21. Duan X, Zhang W, Li X, Wang B. Evaluation of antioxidant property of extract and fractions obtained from a red alga, Polysiphonia urceolata. Food Chem. 2006;95:37-43.

22. Oyaizu M. Studies on the product of browning reaction prepared from glucose amine. Japanese Journal of Nutrition. 1986;44:307-15.

23. Alam N, Bristi NJ. Review on in vivo and in vitro methods evaluation of the antioxidant activity. Saudi Pharm J. 2013. https://doi.org/10.1016/j.jsps.2012. 05.002.

24. Soumya K, James J, Archana TM, Dhanya AT, Shahid AP, Sudheesh S. Cytotoxic and antigenotoxic properties of phenolic compound isolated from the fruit of Terminalia chebula on HeLa cell. Beni-Suef University Journal of Basic Applied Sciences. 2019. https://doi.org/10.1186/s43088-0190017-9.

25. Keller AC, Ma J, Kavalier A, He K, Brillantes AB, Kennelly EJ. Saponins from the traditional medicinal plant Momordica charantia stimulate insulin secretion in vitro. Phytomedicine. 2011. https://doi.org/10.1016/.jphymed.2 011.06.019.

26. Roderigo-milne H, Hauge-evans AC, Persaud SJ, Jones PM. Differential expression of insulin genes 1 and 2 in MIN6 cells and pseudoislets. Biochem Biophys Res Commun. 2002;296:589-95

27. Zlatkina V, Karaya O, Yarmish N, Shalimova A. Trigger mechanisms in insulin resistance and diabetes mellitus development. Vessel Plus. 2019;3:7. https:// doi.org/10.20517/2574-1209.2019.03

28. Poitout V, Hagman D, Stein R, Artner I, Robertson RP, Harmon JS. Regulation of the Insulin Gene by Glucose and Fatty Acids. Recent Advances in Nutritional Sciences 2018; 873-876

29. Pugliese A. The insulin gene in diabetes. Diabetes Metab Res Rev.2002;13-25.

30. Harmon JS, Gleason CE, Tanaka Y, Oseid EA, Hunter-Berger KK, Robertson RP. In vivo prevention of hyperglycemia also prevents glucotoxic effects on PDX-1 and insulin gene expression. Diabetes. 1999;48(10):1995-2000. doi: https://doi.org/10.2337/diabetes.48.10.1995.

31. Park MH, Han J. Padina arborescens extract protects high glucose-induced apoptosis in pancreatic $\beta$ cells by reducing oxidative stress. Nutrition Research Practice. 2014. https://doi.org/10.4162/nrp.2014.8.5.494.

32. Tajiri Y, Grill VE. Aminoguanidine Exerts a fi-cell Function-preserving Effect in High Glucose-cultured fi-cells (INS-I). Int Jnl Experimental Diab Res. 2000. https://doi.org/10.1155/EDR.

33. Ithami Gulcin AO. Irfan Kufrevio Glu, Munir Oktay, Mehmet Emin Buyukokuro Glu. Antioxidant, antimicrobial, antiulcer, and analgesic activities of nettle (Urtica dioica L.). J Ethnopharmacol. 2014;90:205-15.

34. Zhang Y, Liu D. Flavonol kaempferol improves chronic hyperglycemiaimpaired pancreatic beta-cell viability and insulin secretory function. Eur J Pharmacol. 2011;670(1):325-32. https://doi.org/10.1016/..ejphar.2011.08.011.

35. Chotphruethipong L, Benjakul S, Kijroongrojana K. Ultrasound-assisted extraction of antioxidative phenolics from cashew (Anacardium occidentale L.) leaves. J Food Sci Technol. 2019;56(4):1785-92. https://doi.org/10.1007/ s13197-019-03617-9.

\section{Publisher's Note}

Springer Nature remains neutral with regard to jurisdictional claims in published maps and institutional affiliations.

\section{Submit your manuscript to a SpringerOpen ${ }^{\circ}$ journal and benefit from:}

- Convenient online submission

- Rigorous peer review

- Open access: articles freely available online

- High visibility within the field

- Retaining the copyright to your article

Submit your next manuscript at $\boldsymbol{\nabla}$ springeropen.com 